Research Article

\title{
POPULAR CULTURE AND CONSUMPTION CULTURE EFFECT IN ADVERGAME
} ADVERGAME UYGULAMALARINDA POPÜLER KÜLTÜR VE TÜKETIM KÜLTÜRÜ ETKISİ

\author{
İpek SUCU YAZAR ${ }^{1}$ \\ ${ }^{1}$ Dr. Öğr. Üyesi, Reklam Tasarımı ve İletişimi Bölümü, İktisadi, İdari ve Sosyal Bilimler Fakültesi, İstanbul Gelişim Üniversitesi, İstanbul, \\ Türkiye, isucu@gelisim.edu.tr ORCID: 0000-0002-6298-7918
}

\section{Article Info:}

Received : January 23, 2020

Revised : April 18, 2020

Accepted : June 22, 2020

\section{Keywords:}

Advertisement

Advergame

Brand

Popular Culture

Consumption

\section{Anahtar Kelimeler \\ Reklam \\ Advergame \\ Marka \\ Popüler Kültür}

Tüketim

DOI: $10.46238 /$ jobda.679235

\begin{abstract}
Advertising work, which has become one of the most important concepts of the century, is a promotional campaign used by businesses to promote a product or service. Advertising has gained value due to the widespread use of mass media and new media channels. It is seen that it meets the needs of the consumer society through brands, due to the increasing popularity of advertising areas. In this regard, the media sector offers consumption with the promise of satisfying people through advertising. With the development of today's technologies, brands have turned to both entertain and use the product promotion method. One of the successful applications provided by the new media in the field of advertising is Advergame (Ad Game) applications. Successful advertising strategies are made possible through Advergame applications and encompass consumers with integrated messages. Thus, exceeding the perception thresholds of consumers is accelerated. In this study, the contribution of brands' Advergame applications to brands will be emphasized. In the study, literature review and analysis of brands' advergame applications were used.
\end{abstract}

\section{ÖZET}

Yüzyılın en önemli kavramlarından biri haline gelen reklam çalıșmaları bir ürünü veya hizmeti tanıtmak için işletmeler tarafından kullanılan bir tanıtım kampanyasıdır. Reklamcllık kitle iletişim araçlarının ve yeni medya kanallarının yaygınlaşmasına bağlı olarak değer kazanan bir sektör olmuştur. Reklam alanlarının giderek yaygınlaşmasına bağlı olarak tüketim toplumunun ihtiyaçlarını markalar aracılığıyla karşıladığı görülmektedir. Bu konuda medya sektörü, reklam aracilığıla insanlara tatmin olmak vaadiyle tüketimi sunmaktadır. Günümüz teknolojilerinin gelişmesiyle markalar hem eğlendirip hem ürün tanıtma yöntemini kullanmaya yönelmişlerdir. Yeni medyanın reklam alanında sağladığı başarılı uygulamalardan biri Advergame (Reklam Oyun) uygulamalarıdır. Advergame uygulamaları ile başarılı reklam stratejileri yapılmasına olanak tanınmakta ve tüketicileri bütünleștirilmiş mesajlarla kuşatmaktadır. Böylece tüketicilerin algı eşiklerinin aşımı hızlandırılmaktadır. $\mathrm{Bu}$ çalışmada markaların Advergame uygulamalarının markalara katkısı üzerinde durulacaktır. Çalışmada literatür taraması ve markaların Advergame uygulamaları incelenmesinden yararlanılmıștır. 


\section{1| GİRIŞ}

1980 sonrası dönemde yeni tüketim kalıplarının oluşmasıyla birlikte ürünlerin çeşitliliğinde artış görülmüştür. Bunda Dünya ekonomik sisteminde olmanın etkisi büyük çaplı olmuştur. Örneğin, 1980 dönemi piyasanın, teknolojinin azlığından ötürü ürünler kişiye göre özel üretim yapılırken sanayi devrimi sonrası teknoloji ilerledikçe, makineleşme arttıkça fabrikalarda stoklar ve çeşitlilik artar bununla beraber özellikle giyim, klyafet ve modellerle birlikte tüketim artmaktadır. Modern kapitalist toplumun en temel dayatıcı güçlerinden biri de tüketim kültürüdür. Tüketim kültürü bize sahip olmadığımız paraları harcatmaktadır. İnsanlar tükettikçe mutlu olduklarını hissederler ancak bu mutluluk geçicidir ve gerçek değildir. Markaların yeni uygulamalarının her zaman daha çekici olduğu ve kişilerin sosyal statüsünü arttırdığı ve yaşam tarzlarını oluşturduğu düşünülmektedir. Tüketiciler bir yönde yeterince tüketmeden önce mutlu olamaz, tüketirken mutlu olur ve tükettikten sonra yine mutsuz olur hatta bir zaman sonra yeniden tüketme isteği gelir ve tekrar tüketim yapılarak doyum elde edilmeye çalışılır. Bu bağlamda, tüketiciler ne kadar fazla tüketirse o kadar mutlu olmaları yönünde imaj çalışmaları yaygın olarak kullanılmaktadır.

Kitlelere tüketim düzeyinde bir haz ve mutluluk ihtiyacının benimsetilmesi, hızlı tüketim edinimlerinin toplumsal etkilerden ve gerçeklerden soyutlayarak kapitalist çerçevede keşfedilmesine ve bu yönde artan ticari bir ilginin oluşturarak markaların önem kazanmasına katkıda bulunmuştur. $\mathrm{Bu}$ yönde tüketim ağı aracılığıyla tüketimle birlikte tükenmeye gitmektedir. Bireylerin toplumsal konumları ve çıkarları yönünde algılamalarını engelleyen yanlış ihtiyaçlar ve yanlış bilinçlilik durumu daha ilerleyen yillarda tüketimin boyut değiștirerek, tüketim eyleminin bilinçsiz olmasına sebep olmuştur (Özbek, 2002, s.66). Günümüzde kitle iletişim araçları ve bu araçlarla birlikte oluşan küresel pazarda ürün, hizmet ve ideolojiyle birlikte karar verilmeye başlanmıştır. Popüler kültür çapında da bu kültürün kitle üretimi pazarında gelişmesi ve bu yönde yeni iletişim araçlarını ve özellikle Advergame uygulamalarını kullanmaları tüketimin yeniden şekillenmesine yol açmaktadır. Bu çalışmada; Advergame uygulamaları literatür kapsamında değinilecek ve popüler kültür ve tüketim yönündeki etkileșimleri Advergame örnekleri üzerindeki incelenecektir.

\section{2 | KAVRAMSAL ÇERÇEVE}

\section{1| Popüler Kültür ve Tüketim Kültürü Bağlamında Reklam Çalışmaları}

Popüler kültür, politik düşünceden, dinsel ya da toplumsal etkinliklere, tüketime ve yaşam tarzlarına kadar pek çok değișkeni etkileyen bir kültür düzenidir. (Barnet ve Cavanagh, 1995, s. 21). Popüler kültür terimi özellikle günümüz teknolojisindeki gelişmeler neticesinde toplumda tanınan bireylerin davranış kalıplarını, tüketim edinimlerini ve yaşam tarzlarını daha yakından takip edilebildiklerine neden olmaktadır. Sosyal medya platformlarının artması ve bu platformları kullanan kullanıcı sayısının giderek artması sosyal medyada takipçi sayısı fazla olan kişilerin popüler olmasını sağlamaktadır. Popüler olan kişilerin takipçileri tarafından taklit edilmesi bu yönde popülerliğin geniş bir kesim tarafından önemli sayılmasına vurgu yapmaktadır. Popüler kelimesi TDK'da şöyle tanımlanmaktadır: "Halkın arasında yașayan motiflere, ögelere yer veren, onlardan yararlanan, halkın zevkine uygun, halk tarafindan tutulan." (TDK) Aynı șekilde popüler kültür kavramı da özellikle teknolojiyle beraber hızla gelişen sosyal medya yardımıla günümüzde sıkça duyduğumuz kavramlardan biridir. Sözlügüüüzdeki tanımı: “Belli bir dönem için geçerli olan, hızlı üretilen ve hızlı tüketilen kültürel ögelerin bütünü." (TDK) "Kültür, belli bir topluluğun belli zaman ve koșullarda üretim biçimindeki sosyal kişiliğidir." (Erdoğan,1999, s.2).

Popüler kültüre olumlu yönde yaklaşan yaklaşımlar bir toplumda karşı duruş veya bir direniş göstergesi olarak yerelliği ön plana çıkartmaktadır. Bu yönde popüler kültür ideallerin oluşmasında ve şekillenmesinde önem taşımaktadır. Gündelik yaşam kültürü çerçevesinde bireyler metalaşmış, ucuz ve çaba gerektirmeyen, geçici ürünleri popüler eğlence endüstrisi içerisinde kültürü egemen olmaya yönelmiștir (Kahraman, 2003, s. 12; Oskay, 1998).

Bireyler sürekli yeni nesillere kendi yaşam biçimlerini aktarırlar. Ancak teknolojiyle beraber kültürler ve yaşam biçimleri hızla değişmektedir. Kullanıcı deneyimi olarak marka uygulamaları hem kullanıcılara zaman kazandırmakta hem de markaların teknoloji bazında gelişimine katkı sağlamaktadır. "Popüler kültür hem halkın kendisi için ve kendisi tarafindan üretilen kültür olarak, hem de kendisi için üretilen, yönetilen bir kültür olarak tanımlanabilir" (Kurtuluş, 2014).

Popüler kültür, popüler olanın kullanılması ve bu yönde tüketiminden daha fazla haz alınmasını amaçlamaktadır. Popüler kültür, yeni iletişim teknolojileri üzerinden de hız kazanmaktadır. Advergame çalışmalarının popüler bir konuma gelmesi, markaların kazanımlarının artmasına yardımcı olmaktadır. Markaların reklam çalışmalarında popüler ögelerin kullanımını baz alırken, bu yönelimi yeni popüler araçlar üzerinden yapmaya özen göstermektedirler. Markanın tüketim ediniminin artması yönünde reklamların ilgi çekici olması önem taşımaktadır. Bu yönde, Advergame çalışmaları popüler bir araç konumuna yerleşerek, reklamlara olan ilgi çekiciliğin artmasını sağlamaktadır. 
Tüketim kültürü, yeni ihtiyaçların oluşturulması ve ihtiyaçların sürekli olması prensibi üzerine odaklıdır. Yeni ihtiyaçlar oluşturularak satın alma arzusunun sürekli sağlanma olgusu, üretim ve tüketim ve kâr döngüsünün yürütülmesidir. Öte yandan, üretilen ürünlerin verimli olarak tüketilmesine hizmet etmektedir. Böylece, ihtiyaçlar ve ürünler, kişiler ve nesneler arasındaki ilişki, kapitalizmin aracı olmuştur (Yanıklar, 2010). İletişim teknolojilerinin gelişmesi tüketim yönünde popüler kültür ürünleri kullanımının önemli bir kısmını büyük bir kitle, tüketme olanağına sahip hale gelmiştir. Popüler kültürün egemen olması yalnızca belirli ürünleri, kullanımları, etkinlikleri popüler kılmamaktadır. Bunlarla birlikte birbirleriyle etkileşim halinde olan dünya görüşlerini ve düşünme biçimlerini de popüler hale getirmektedir.

Bireylerin fizyolojik, biyolojik, sosyal ve kültürel açıdan çok ihtiyacı bulunmaktadır ve bu ihtiyaçların giderilmesi için harcanan maddi ve manevi değerlerin kullanılması da tüketim olarak tanımlanmaktadır. (Torlak, 2000, s.17) İhtiyaçlar sınırsızdır. Bireylerin yaşamlarını devam ettirebilmesi için karşılanması gereken temel ihtiyaçlar dışında ihtiyaç duyulmayan ama sahip olunan pek çok gereksinim de mevcuttur. $\mathrm{Bu}$ yönde popüler kültür ve reklam kampanyaları sayesinde tüketim ediniminin daha fazla artması ve rağbet görmesi söz konusudur.

Tüketim kültürü, post-modern kültür veya medya kültürü olarak adlandıran kültür yaşamın her alanını kuşatmaktadır. Televizyon dizileri aracılığıyla izleyicilere gösterilen farklı yaşamlar, imajlar, kişilikler, giyim ve mücevher modaları, evlerin dekorasyonu ve mobilya modaları, farklı aktiviteler ve gündelik yaşam faaliyetleri popüler kültürü ve tüketim kültürünü oluşturmaktadır. Televizyon dizileri ile olușturulan popüler kültür tüketime yansıyarak tüketim ürün ve hizmetlerini artırmaktadır. Bu bağlamda televizyon dizileri birer reklam aracı haline gelmiștir. Son zamanlarda televizyon dizilerinde özellikle cep telefonu, bilgisayar, mekan yerleri, müzik, parfüm, giyim ve mobilya markaları pazarlanmaktadır. Modern kapitalist toplumun en temel dayatıcı güçlerinden biri tüketim kültürüdür. Tüketim kültürü bireylere yüksek düzeyde tüketim yaptırmaya özendirir. Bireyler tükettikçe kendilerini daha mutlu hissederler ancak bu mutluluk geçicidir ve çoğu zaman sürekli bir gerçeklik düzeyinde değildir.

Geleneksel pazarlama yöntemlerinden farklı bir yönde yeni iletişim kanallarıyla tüketicilerle pozitif bağ kurulmasını amaçlanmaktadır. Kullanıcıların markayla birebir kurgusal bir birliktelik içerisinde olması ve bu birliktelikte reklamları oyunla bağdaştırması, içeriklerin daha fazla akılda kalıcı olmasını sağlamaktadır. Böylelikle oyunlar aracılığıyla reklam mesajlarının iletilmesine aracılık eden Advergame uygulamaları markaya iletilerin tüketiciye ulaşmasına imkân tanımaktadır. Tüketicinin interaktif katılımının sağlanması uygulamaların kullanımında etkin bir role sahip olmaktadır. Kullanıcılara eğlenceli ve keyifli bir ortam sunularak markaların yeni reklam amaçlarını gerçekleştirmelerine olanak sağlayan Advergame'ler, tüketici veri tabanı oluşumunu da sağlamaktadır. Bu oyunlara katılan kullanıcılar, bir oyuncu karakterine bürünür ve markanın kurgusal olarak yaratmış olduğu öyküye tanıklık ederler. Böylelikle kullanıcı ile marka arasında duygusal yönde bir bağın kurulması sağlanmakta ve marka sadakati de daha fazla sağlanabilmektedir (Yamamoto, 2009). Yeni iletişim teknolojilerinin yaygin bazda kullanılması, Advergame kullanıcılarının sayısında da her gün büyük artışların olmasına olanak vermektedir. Bu yönde sayıların artışıyla birlikte tüketiciye ulaşma yönünde yeni medyanın önemli bir rol üstlenmesine katkıda bulunmaktadır. Yeni medya bu yönde yeni pazarlama türlerinin uygulandığı bir ortam haline bürünmüştür.

\section{2 | Reklam Çalışmalarında Yeni Bir Teknoloji Olarak Advergame}

Advergame, reklam mesajlarını ve imgelerini birleştiren web tabanlı bir bilgisayar oyunudur. Reklamın içerisine oyun entegre edilerek eğlencenin yanında bir reklam aracıdır (Santos et al., 2007, s.203208). Advergame uygulamaları yeni iletişim teknolojilerini yoğun olarak kullanan bireyler için son derece yenilikçi, eğlenceli ve marka deneyimi yaşatan uygulamalardır. Advergame çalışmaları ağızdan ağıza iletişim kanalını da kullanarak viral yayılım özelliklerini de sağlamaktadır. Bu yönde oyun içerisinde markayla ilgili sahip olunan tüm bilgiler oldukça hızlı bir biçimde yayılır ve duyulurlar. Günümüzde bireylere ulaşmanın en etkili yollarından biri oyun yerleștirilmiş reklamlar ve ya web sitesi içerisine yerleştirilmiş kendine özgü bir şekilde marka farkındalı̆̆ uygulamalarıdır. (Yüksel, 2007, s.318). Advergame uygulamaları yeni iletişim teknolojileri kanalları için hazırlanan reklam amaçlı yönde bilgisayar oyunlarıdır. Kurgulanan oyunlara yönelik marka imajını destekleyen mesajlar yerleştirilerek yeni bir pazarlama biçimi ortaya konmaktadır. Bu yönde, pazarlama içerikli mesaj içerikleri sayesinde marka bilinirliğini interaktif yollarla artırılmaya çalışılmaktadır.

Advergame oyunlar üzerinden pazarlama ve reklam faaliyetlerinin pazarlama dünyasına katılan yeni bir yöntemi olarak göze çarpmaktadır. Oyunlar üzerinden pazarlama ve reklam faaliyetlerinin geliştirilmesi müşterilere çok sayıda reklam mesajlarını gönderme yönünde etkileşimli oyun teknolojilerini kullanılmaya başlanmıştır (Marolf, 2007, s.12). Oyuna dayalı reklam mecralarında reklam veren markalar, ürünleri yönünde markayı bir yaşam tarzı ve ya bir aktiviteyle bağdaştırma 
yönelimi içerisine girerler. Advergame uygulamaları kullanıcıların çeşitli statülerde olabileceği ve rol üstlenebildiği ilginç bir dünyaya kapılarını açmaktadırlar. Bu dünyanın gerçek bir dünya olmaması kullanıcıların reklamlardan olumsuz olarak etkilenmesine neden olmamaktadır. Oluşturulan bu kurgusallık, kullanıcıların kendi oluşturduğu yüksek motivasyona ve marka algısına hizmet eder.

Temelinde eğlence odaklı tasarlamasına sahip Advergame uygulamaları, hedef kitlelerindeki tüketici gruplarına farklı video oyunlarında yaşanan eğlence deneyimine benzer nitelikteki deneyimler yaşatmaktadır. $\mathrm{Bu}$ eğlenceli dünya içerisinde kullanıcılar oyun içerisine yerleştirilen marka ve ürünler aracılığıyla marka ile tüketici arasında olumlu ilişkiler oluşturmayı amaçlamaktadır (Bozkurt 2016, s.522). Advergame, hedef kitleler üzerinde marka etkisini olumlu yönde oluşturmak ve markanın akılda kalıcılığını artırmayı hedef almaktadır. Tüketicilerin satın alma önceliklerinde marka algısı yönünde değişiklikleri sağlayabilmek için, markalar bir yandan hedef kitleyi eğlendirirken diğer bir yandan da marka farkındalığı oluşturmaya yönelmektedirler (Oskay, 2016, s.44). Advergame uygulamaları, ilk uygulamaları sırasında daha çok çocuklara ve gençlere hitap eden ürünler yönünde çalıșmalar yapmıştır. $\mathrm{Bu}$ yönde, popüler kültür çerçevesinde ürünün yönlendirildiği yaş grubu ve ürün özelliklerini bazında hedef kitlenin sosyal eğilim ve zevkleriyle bağlantılı reklam kampanyaları çapında oyunların geliștirilmesi sağlanarak yetişkin kullanıcıların da ilgisi çekilmeye başlanmıştır. Ürünlerin tüketicilerle yakın bir iletişim halinde olması Advergame'lerin markaya ve ürüne kazandırdığı önemli avantajlardan biri olmuştur (Aktaş vd. 2010, s.657).

Reklamı oyun içerisinde kullanmak 1980'li yıllardan beri reklamcıların akıllarında olan bir çalışma olmuștur. O dönemlerde sıklıkla kullanılan Atari, Comodore 64 gibi oyun konsolları aracılığıyla oynanan oyunların içerisine reklamlar yerleștirilmeye başlanmıştır. İlerleyen dönemlerde yeni iletişim teknolojilerinin gelişmesi ve kullanıcı sayılarının çoğalmasıyla birlikte bazı markalar Advergame uygulamalarının ilk örnekleri oluşturmaya başlamışlardır. Bu yönde, Domino's Pizza (1989) Avoid the Noid oyunu ve 7-Up'ın (1993) Cool Spot oyunlarını yayınlamışlardır (Öztürk ve Coşkun, 2017, s.51-52). Markalar ilerleyen yıllarda özel oyun siteleri üzerinden kendi hedef kitlelerine özel Adverge uygulamaları ile tüketici verilerini toplamaya ve ürünlerin reklamlarını yapmaya yönelmişlerdir (Özkaya, 2010, s.468). Advergame'ler reklam ve video oyunlarını birleștirerek eğlenceli ve sürükleyici kurgusal bir ortam yaratmışlardır (Ilgın, 2013, s.26-27). Son dönemlerde markaların kendi web sitelerinde markanın oyun için oluşturduğu özel bir web sitesinin de geliştirildiği görülmektedir. Markanın oyunuyla ilgili forum sitelerinde ve pek çok bağlantılı web sayfasında çevrimiçi Advergame uygulamalarına rastlanmak mümkündür. Günümüzde pek çok küresel marka tarafından bu uygulamalar yaygin olarak hizmet vermektedir (Özkaya, 2010, s.468).

Advergame uygulamaları etkileşimli iletişim ortamı sunarak reklam alanına hizmet etmeye yönelmiştir. Markanın hedef kitlesi yönünde marka bilinirliliğinin artırılması amaçlanmaktadır (Oskay ve Koçer: 2016, s.124). Advergame, reklamı oyun içerisinde sunarak gelişen teknolojiye ayak uydurmayı başaran ve tüketici kitlelerine kişiselleştirilmiş post-modern pazarlama ilkelerine uyumlu mesajlar ileterek ürünlerin tanıtımını yapmaktadır. Yeni bir reklamcılık anlayışı oluşturulmakta ve bu yönde etkileşimi ön planda tutan bu uygulamalarla, markalar için yeni bir iletişim aracı olarak karşımıza çımaktadır (Öztürk ve Coşkun, 2017, s.52). Son dönemlerde çok daha fazla ilgi görmeye başlayan ve önem kazanan Advergame uygulamaları, günümüzde reklamcıllk platformunda yeni bir reklam iletişim aracı konumundadır. Dünya'da ve Türkiye'de özellikle etkileşimli reklam uygulamaları ve Advergame uygulamaları yönünde reklam firmalarıyla özel olarak etkileşimli reklam kanalları oluşturmak mümkün hale gelmiştir (Akyol, 2010, s.106). Advergame uygulamaları interaktif oyun teknolojisini içinde barındırmaktadır. $\mathrm{Bu}$ yönde kullanıcıların zihnine markanın iletmek istediği mesajların aktarılması ve marka farkındalığının sağlanması aşılanmaktadır (Özkaya, 2010, s.468). Advergame uygulamaları marka ve müșteri arasında karşılıklı bir trafiği oluşturur. Bazı müşteriler ödül kazanma amaciyla ya da promosyondan faydalanma isteğiyle kişisel bilgileriyle üye olmaktadırlar. Bu durum da reklamcılara müșteri verilerinin teminini sağlamaktadır. Ayrıca müșterilerin arkadaşlarını da bu tarzda promosyonlu sitelere davet etmesiyle mevcut müşteri sayısında artış oluşabilmektedir

\section{3 | Türleri ve Uygulamaları Açısından Advergame}

Advergame uygulama türleri üç grupta toplanmaktadır: ATL Advergaming (çizgi üstü oyun reklam), BTL Advergaming (çizgi altı oyun reklam) ve TTL Advergaming (çizgi boyunca oyun reklam) (Perez, 2010).

ATL Advergaming (çizgi üstü oyun reklam): ATL oyun reklam uygulamaları, ürüne ya da markaya özel sunulan uygulamalardır. Bu uygulamalarda oyunun sunduğu marka çalışmaları sayesinde, potansiyel müşterilerin markanın web sitesinde daha fazla vakit geçirmesine olanak tanımaktadır. Bu sayede, ürünler veya hizmetler hakkında daha fazla haberdar olması amaçlanmaktadır. $\mathrm{Bu}$ oyunlar genel olarak markaların ürünlerini doğrudan bir şekilde sunmaktadır. Oyun sırasında sıklıkla markayla ilgili olarak önemli bilgiler kullanıcılara iletilmektedir. ATL uygulaması için Intel tarafından eski bir 3D real-time 
oyunu olan IT Manager Game'i alarak Toyota markası için yeniden uyarlaması verilebilir. İnternetin günlük hayatta yoğun olarak kullanılmasından önceki dönemlerde floppy disk kullanılan dönemlerde, eski özel yapım video oyunlar, entegre sağlanmış bir biçimde marka mesajları verme yöneliminde olmuştur. Taşınabilir disklerde gelen ilk Advergame uygulama örnekleri niteliğinde olmuștur. Bu yönde markalar reklam amacina hizmet ederken dikkat çekici bir şekilde marka mesajlarını verme amacı taşımışlardır. American Home Foods Chef Boyardee markası ilk disket medyasını kullanarak Advergame çalışmasını piyasaya sürmüştür. CocaCola ve Taco Bell markaları çocuklar için hazırladığı oyunların CD`den oynanmasına olanak sağlamıştır. Temizlik robotu Dyson markası, bir teknoloji markası olan Intel ve ilaç firması olan Nurofen markası oyunları bu yöndeki ilk çalışmalardan olmuştur. Pepsi ve 7 Up içecekleri için oluşturulan oyunlarda ilk olarak oyun kahramanları (Pepsiman ve Cool Spot) marka karakteri olarak kullanılmıştır (Akyol, 2010, s.99102). Advergame uygulamaları bu yönde basit oyun prensibi içerisinde olan ve kısa süreli oynanan oyunlar kapsamındadır. $\mathrm{Bu}$ oyunlar genellikle markaların kendi internet siteleri üzerinden oynanmaktadırlar Böylelikle ürün tanıtılması ve verilmek istenen mesajlar oyun üzerinden iletilerek marka bilinilirliği artırılmaktadır.

BTL Advergaming (çizgi altı oyun reklam): bu tür Advergame uygulamalarında dikkat çekmeyi hedef alan sosyal ve ekonomik konulara yönelik uygulamalar bulunmaktadır. Bu tarzdaki oyunlar normal bir oyun tarzında yayınlanır ve kullanıcıların konuyla alakalı daha fazla araştırma yapması amaçlanır. BTL türüne örnek olarak Militainment, Recruitment Tools, Edutainment ve Oyun-içireklamcllık verilebilir. $\mathrm{Bu}$ Advergame türünde sunulan reklamlar politik veya eğitimle ilgili konulara yönelik içerik barındırmaktadır. Bu tür oyunlara örnek çapında Amerika Birleşik Devletleri'nin orduya ve özel güçlere olan katılımın daha fazla olması amaciyla oluşturduğu bir oyun olarak America's Army, 7Up ve Pepsi markalarının oyunlarında kendi maskotları niteliğinde kullandıkları Cool Spot ve Pepsiman içinde bulunduğu oyunlar verilebilir. Son dönemlerde ise, bu yönde Burger King markasının kendi maskotu The King'in bulunduğu King Games örnek gösterilebilir. United Nations' World Food Program tarafindan verilen Food Force ve Urban Jungle ve eğitim içerikli olarak oluşturulan trafik simülasyonu bu çalışmalar içerisinde yer almaktadır (Akyol, 2010, s.99-102). Bu türdeki Advergame uygulamalarında oyunun içinde kendi reklamları bulunmaktadır. Advergame uygulamaları bu yönde bir yandan reklam amacını sağlarken diğer bir yandan da reklamları politik durumları da içerisinde barındıran ancak daha çok ticari kaygıyı göz önüne alan bir yaklașımla sürdürür. EA Sports tarafından yapılan FIFA oyununda, futbol stadyumunun diş kenarlarlarında yer alan reklam panolarında gerçek reklamlara yer verilmiştir. Ücretsiz kısa zamanlı internet tabanlı oyunları içerisinde gösterilen bannerlar da Advergame uygulamalarında sıklıkla kullanılmaktadırlar. $\mathrm{Bu}$ türdeki uygulamalarda oyuncuların oyunlara rağbet göstermesiyle birlikte, oyunu tasarlayanların reklamdan para kazanması da sağlanmaktadır.

TTL Advergaming (Cizgi Boyunca Oyun Reklam): bu Advergame uygulaması diğer uygulama türlerine göre daha seyrek görülen bir türdür. Bu türde, çevrimiçi oyun sitelerinde sergilenen ürünle ya da markayla bağlantısı sunulan oyunlara sponsor olunmaktadır. Böylelikle ürün görselleri ve reklam sloganı kullanıcılara iletilmektedir. TTL Advergame uygulamalarında, kullanicıların BTL Advergame türünde reklamları bulunan bir siteye ziyaret etmelerini sağlayacak URL linkleri bulunmaktadır. Kullanıcıların bu sitelere ziyaretlerinin sağlanması için farklı türlerde ikna etme yöntemleri kullanılabilmektedir. Örneğin, Pikmin2 tarzındaki Advergame uygulamalarında oyunlarda kullanıcıları merakta birakacak tarzlarda gizli bir mesaj URL aracılığıla oyuncuya iletilmektedir. Enter the Matrix, Year Zero, I Love Bees ve Lost Experience gibi oyunlarda ise URL linkleri oyunun arka planında bulunmaktadır. Kullanıcılar oyundaki bazı detayları yalnızca bu link vasıtasıyla görülebileceği iletilir (Akyol, 2010, s.99-102). Bu şekilde verilen farklı detaylar oyunun istenilen şekilde oynanmasını ya da bitirilmesini engellemediği gibi aynı zamanda kullanıcıların daha fazla haz almasını sağlamaktadır. $\mathrm{Bu}$ türdeki Advergame uygulamalarında açılan sayfalan başka linkler aracılığıyla oyuncuların farklı sitelere yönlendirilmesi de sağlanır. Yeni iletişim teknolojilerinin Advergame kullanımlarının daha fazla rağbet görmesini sağlayarak markanın web sitelerinin daha fazla ziyaret edilmesine olanak tanımaktadır.

Advergame uygulamaları verdikleri mesajlara yönelik de oluşmaktadırlar. Advergame uygulamaları ürünün pasif bir şekilde arka plana yerleştirilmesi ya da oyunun iç yapısında oluşturması yönünde farklı düzeylerde markanın tanıtımı yapabilmektedir (Dahl et al., 2006). Chen ve Ringel (2001) yaptıkları sınıflandırmaya göre Advergame uygulamalarını marka ve mesajın oyun içine entegre edilme yöntemine göre üç sınıfa ayırmıştır (Chen, Ringel, 2001, Buckner et al., 2002): Çağrışımlı Advergame, Görsel ya da İllüstrasyon Advergame ve Gösterim Advergame.

Cağrışımlı (Associative) Advergame: En düşük düzeyde nitelendirilecek bütünleştirmeleri ifade etmektedir. Genellikle oluşturulan oyunun arka planında ya da oyun içine yerleştirilen dekorlarda markanın logosu gösterilmektedir. $\mathrm{Bu}$ tarzdaki oyunlarda, marka unsurları kullanıcılara yoğun bir entegrasyonla sunulmaktadır. Ürünlerin oyun 
içerisinde bir yaşam aktivitesi yönünde oluşturulması ve marka farkındalığının öne sürülmesi amaçlanmaktadır. Bu türdeki oyunlar, marka farkındalığı oluşumunu yaşam tarzının oluşturulması ve yaşanması yönünde ilişkilendirir. Örneğin Jack Daniel's markası ürünlerini üç boyutlu bir bilardo oyunuyla piyasaya sürerek göstermiştir (Buckner et al., 2002). Türkiye'de Charlsberg bira markasının Dünya Kupası maçları sırasında oluşturulan ve seçilen bir futbolseveri arkadaşıyla birlikte Liverpool'a gönderdiği Advergame uygulaması son derece rağbet gören bir çalışma niteliğinde olmuştur. $\mathrm{Bu}$ hazırlanan içerikte futbol fanatiği olan kişilerin yaşam tarzını uygulama içerisinde barındıran ve buna yönelik soruları içerecek bir şekilde oluşturulmuştur. Bu bağlamda, futbol izleme davranışı ile birlikte bira tüketimi bütünleştirilmiş bir yaşam tarzını çağrıştıracak şekilde bir algı yaratılmıştır.

Görsel ya da Illüstrasyon (Illustrative) Advergame: Chen ve Ringel (2001), ikinci seviyedeki bu Advergame uygulamalarında bütünleștirme biçimlerini, illüstrasyon yaklaşımı olarak adlandırmaktadır. Bu uygulamalarda ürün önemli bir rol oynamakta ve markaya ilişkin nesnelerin ve karakterlerin kullanılması söz konusudur. Özellikle çocuklara yönelik uygulamalar bu Advergame'de oldukça yaygın konumdadır. Ürünün bir karakterle özdeşleşmesi ve gerçek yerine fantezi ya da simülasyon bir dünya yaratılması amaçlanmaktadır. Örneğin, Ülker Cocopops markasının çizgi karakterleri oyunun içinde barındırılmakta ve oyun bu karakterlerin maceraları üzerine oluşturulmuştur. $\mathrm{Bu}$ Advergame uygulamalarında hedef kitle olarak genç ve çabuk etkilenebilir bir hedef kitleyi yakalayabilmek oldukça önemlidir. Bu uygulamalarda, karakterlerin ön planda olmasından dolayı karakterlein yaşadığı maceralar ortamı ürünü gölgede birakarak, hatırlanmasını zorlaştırabilmektedir (Yeygel ve Köseoğlu, 2006, s.5).

Gösterim (Demonstrative) Advergame: $\mathrm{Bu}$ yaklaşımdaki Advergame uygulamalarında gösterim yapılması ve oluşturulması ön planda yer almaktadır. Chen ve Ringel'in (2001) sinıflandırmasına göre, en yüksek seviyedeki bütünleștirmeler oyuncuların ürünü oyun içerisinde aktif olarak kullanmasını sağlayan gösterim türündeki Advergame uygulamalarıdır. (Winkler ve Buckner, 2006). Bu yaklaşımda interaktif kullanım etkin olarak yer almakta, oyun alanlarında ürünün tecrübe edilmesi yönünde tüketicilere Ģans tanınması sağlanmaktadır. $\mathrm{Bu}$ uygulamalarda ürünlerin özellikleri temel öge olarak sunularak tüketicilerin ürünle etkileşime geçmeleri için çağrı yapılmaktadır. Bu çağrılar neticesinde mesajın etkinliği de desteklenmiş olmaktadır. Örnek olarak Nike markasının Nike Shox basketbol ayakkabılarının özelliklerinin tüketicilere test ettirilmesi amacıyla üç boyutlu bir basketbol oyunu Advergame uygulamasının içerisinde verilebilmektedir. Oyun içerisinde bulunan tüketiciler istedikleri zaman Nike Shox ayakkabısını seçerek ürünü birebir tecrübe edebilmektedir (Chen ve Ringel, 2001, s.3-4). Bu uygulamalar tüketicilerin yeni ürünleri Advergame uygulamaları içerisinde kullanarak markaya yönelik kaygılarının azaltılması ve ürünü tecrübe etme imkanını sağlamaktadır.

Dijital mecraların her gün daha fazla reklam verenin tercih ettiği bir alan olması tüketici ile markayı yaratıcı çalışmalar içerisinde etkileşimde buluşturan önemli bir mecra haline getirmektedir. Geleneksel pazarlama metodlarının dışına çıkmak isteyen markalar çevrimiçi mecralarda yer almayı tercih etmektedir (Soytürk, 2008, s.80). Advergame uygulamalarının bu yönde en önemli avantajlarından biri tüketicilerin reklama maruz kaldığının farkına varmadan reklamla buluşmasını sağlamaktır. Geleneksel reklam ortamlarında tüketiciler çok sayıda reklam mesajına maruz kalmasına rağmen çoğunda algılamaları zor olmaktadır. Çoğu zaman ise tüketiciler karşılarına çıkan reklam mesajlarından kaçınma davranışını sergilemektedirler (Elden, 2009, s.552). Bu bağlamda, Advergame uygulamaları tüketicilerin oyun içerisinde eğlenerek yeni reklam mesajlarıyla karşılaşmalarına ve etkileşimli bir şekilde oyun içerisindeki ürünler hakkında bilgi sahibi olmalarını, arkadaşlarını bu uygulamalara yönlendirebilmelerine ve ürünleri bizzat tecrübe edebilmelerine olanak sağlamaktadır.

\section{3 | Advergame Uygulama Örnekleri Açısından Markaların Çalışmaları}

Araştırmaya Markalar ürünlerini sattırmak için sadece oyunlara reklam verme yöneliminde değildirler. Reklam, bir ürünü ya da hizmeti hedef bir kitleye tanıtmak, talep oluşturmak ve hedef kitleyi söz konusu olan ürüne yöneltmek amacıyla kullanılır. Reklamın hangi araçla nasıl yapılacağı; ürüne ve hedef kitlenin özelliklerine göre değişmektedir (Akyol, 2010). Markaların amacı en akılda kalıcı reklam ile kendi ürününü sattırmaktır bu yüzden her çeşit reklama başvururlar. Markalar ürün tanıtımı ve satıșı amacıyla oyun tasarlama yönelimindedirler. $\mathrm{Bu}$ şekilde müşteri eğlenceli bir mecrada ürünü tanıması sağlanarak marka açısından başarılı bir stratejinin uygulaması amaçlanmaktadır (Güney, 2006, s.113114). Advergame, reklam ve oyun kelimelerinin birleşimi ile oluşmuştur. Kavram ilk kez 2001 yılında Wierd dergisinde yer aldıktan sonra hayatımıza girmiştir. Kavram 'eğlendiren reklam' kelimeleriyle Türkçeleştirilmiştir. (Hürriyet, 2006) Advergaming, Kool-Aid ve Pepsi ürünlerinin 1980'lerin başlarından itibaren özellikle Atari 2600 için geliştirilen oyun disketlerinde promosyon olarak dağıtılarak başlamıştır (Ilgın, 2013). Advergame, oyunlar aracılığıla reklam vermek, video oyunu endüstrisinde uzun zamandır kullanılan bir uygulamadır. Ürünleri ve şirketleri tanıtmak için video oyunlarıyla birleştirilmiş reklam sektörüdür. 
Bu yönde, markalar ürünlerinin satışını arttırmak için Advergame uygulamalarına yönelmektedirler.

Advergame uygulamalarıyla ilgili bazı örneklere değinilerek, markaların bu uygulamaları nasıl uyguladığını incelemek amacıyla birkaç örneğe yer verilmiştir.

\section{Atari 2600 Oyunu}

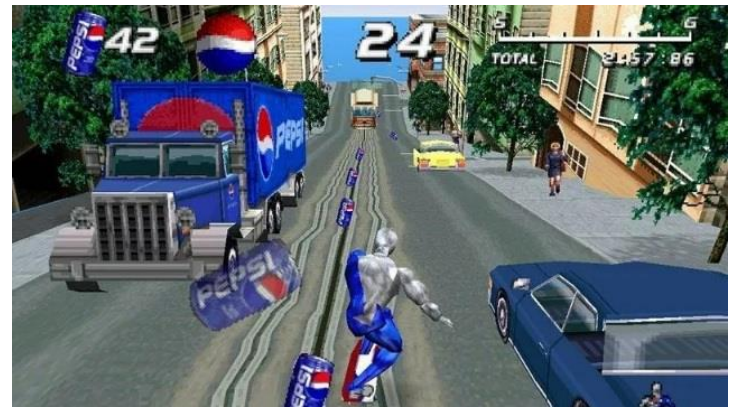

Pek çok ünlü markanın tercih ettiği Advergame uygulamaları, 1980 yılında Pepsi markasının başlattığı ve oyun konsolları uygulamaları ile genişleyen dijital atılımlarla birlikte hızlı bir ilerleme gösterdiği ve birçok küresel marka tarafından tercih edildiğini göstermektedir (Ilgın, 2013, s.28). Advergame uygulamalarının ilk örneği 1980 başlarında görülmüştür. Atari için geliştirilen oyunun içine Pepsi markası yerleştirilmiştir. Kullanıcılar oyunu oynarken hem iyi vakit geçirmekte hem de ürünü görerek bașarılı bir reklam kampanyası yürütmektedirler. $\mathrm{Bu}$ sayede bașarılı bir reklam kampanyası yürütülerek Pepsi satışlarının artırması amaçlanmaktadır. Bu başarı diğer markaların da ilgisini çekerek onların da bu yönteme başvurmalarını sağlamıştır.

$\mathrm{Bu}$ yöntemin en başarılı örneklerinden biri olan "McDonald's Yönet" oyunu dünya çapında ses getirmiș ve milyonlara ulașarak herkesi bir McDonald's sahibi yapmıştır. Oyunun amacı ilaçsız tarım yaparak sağlıklı buğday üretmek, o buğdaylarla inekleri beslemek ve ineklerle et yaparak müşterilere satmak. Üç aşamadan oluşan oyunun her aşamasında kendine özgü zorlukları vardır. Örneğin, tarım yaparken buğdaylar hızlı yetişsin diye ilaçları çok kullanırsanız inekler hastalanıyor ve inekler hastalanırsa hayvan hakları devreye girerek oyunu kaybetmeye yol açmaktadır. Satış kısmında ise mağaza müdürü olarak çalıșanlarla ilgilenme yönünde görevler verilmektedir.
McDonald's Yönet Oyunu

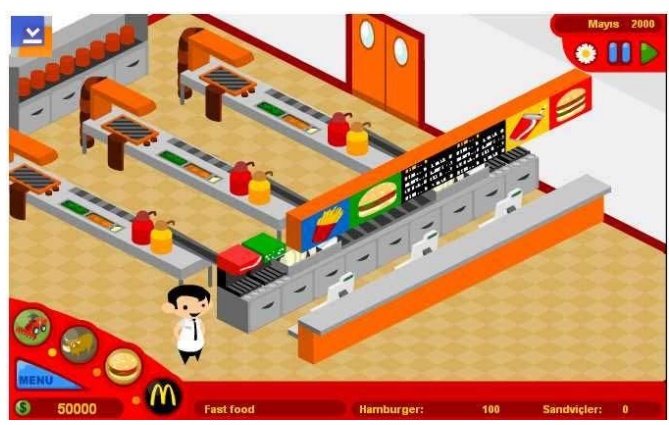

Teknolojinin gelișmesiyle birlikte oyunlar da büyük grafik güncellemeleri geçirmiş ve oyunlarla beraber Advergame olgusu da gelişmiştir. Liberty Media grubunun sabip olduğu Formula 1, gerek reklam panoları gerek araç üzerindeki sponsorlar gerekse pilotların tulumları üzerindeki sponsorlar olmak üzere geniş ve yoğun bir reklam uygulamasını barındırmaktadır.

\section{F1 2019 Kanada GrandPirx}

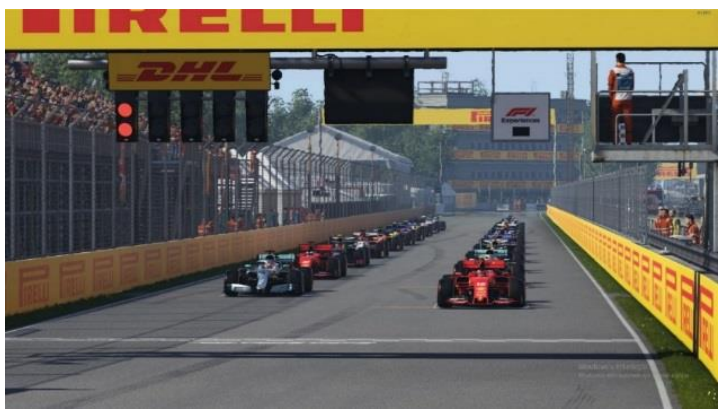

Liberty Media, Formula 1'i daha geniş kitlelere sunmak için CodeMasters's gibi sektörde adını duyurmuş oyun yapımcısıyla anlaşarak yarıșın oyun halini yapmaktadır. Günümüz teknolojisini de işin içine kattığımızda ortaya gerçeğinden zor ayırt edeceğimiz bir oyun ortaya çıkartmıştır. Gerçek yarışlarda sponsorlar ve reklam verenlerin logolarını sıkça gördüğümüz gibi oyun için de ayrı reklam anlaşmaları yapılarak gerçekte gördüğümüz yerlerde oyun içinde de reklamlar görülmektedir.

\section{Max Atlantos oyunu}

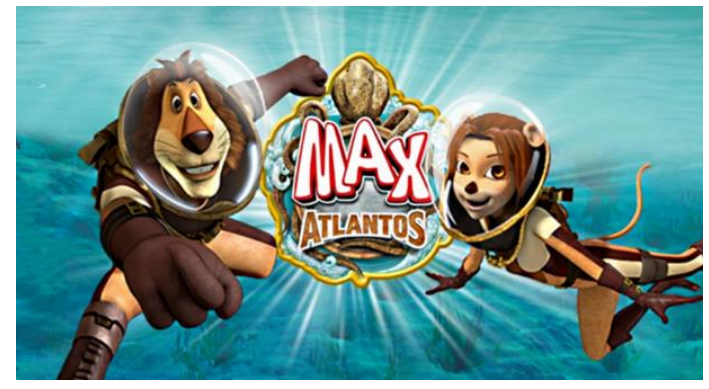

Aslan Max oyunları çocuklara hem eğlenceli ve keyifli deneyimler yaşatmaktadır hem de markasını sunmaktadır. İlgi çekici ve heyecanlı oyunların yer aldığı bölümler, başta Aslan Max ve Leena olmak üzere birçok karakteri de barındırmaktadır. Her 
oyunda değişik maceralara katılan karakterler, oyunlarda toplam puanlarla sürpriz hediyelere sahip olmaya yardım etmektedir. Bu şekilde bu oyunu oynayarak ve puan toplayarak hediye firsatı sunmaktadır. Böylece çocuklara bol oynandığında, hediye kazanma şansı arttırdığını öne sürerek oyunun sürekli oynanmasını sağlamaktadır. Her macerada Max ile ilgili ipuçları ve destek bölümleri yer almaktadır. Dinozorlar dünyası, okyanus yaşamı, yağmur ormanları gibi coğrafyalarda geçen maceralarla eğlenirken aynı zamanda birbirinden değişik ve ilginç bilgiler edinebilme imkânı sunmaktadır. Yani oyun içeriğini zengin tutarak oyun cazip hale getirilmektedir. Ayrıntılar içeren gizli görevler, Max ürün çeşitlerini içeren bulmacalar ile hayal dünyasını geliştiren yapboz oyunları, sorun çözme becerilerini geliștirmektedir. Yapılan çizim ve tasarımları arkadaşlarıyla paylaşabilme veya bilgisayara indirerek saklayabilme olanağ sağlamaktadır. Hayal gücünü yansıtma alanları da içinde barındırmaktadır.

\section{Tutkuna Sahip Çık Oyunu}

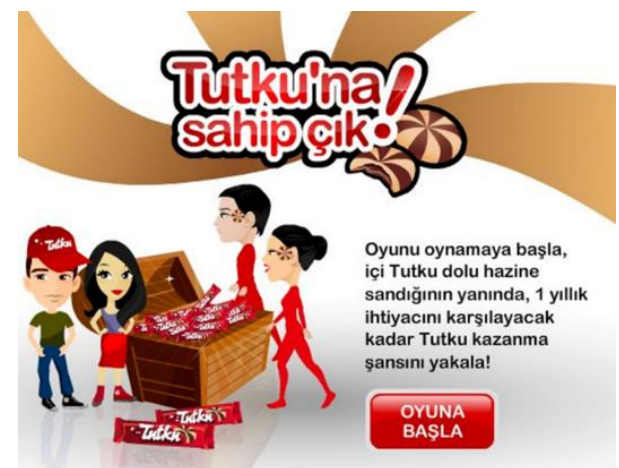

“Tutku'na Sahip Çık!” isimli Facebook oyunu tüm Facebook kullanıcılarını çetin bir maceraya davet etmektedir. Hazinelerini korurken oyuncuların yanlarında bir Tutku paketi bulundurması onlara ayrıca yardım sağlamaktadır. Tutku'suna en iyi şekilde sahip çıkıp, günün birincisi olan oyuncu, içi Tutku dolu hazine sandığı kazanmaktadır. 25 gün devam eden oyunun sonunda en yüksek puanı alan oyuncu, bir yıllık Eti Tutku sahibi olmaktadır. $\mathrm{Bu}$ oyunun işlevi de diğerlerinde olduğu gibi ürünü tanıtmak amaciyla bir oyun dizayn etmiştir. Ve oyun düzeninde rekabet ile en yüksek puanı alana tutku ödülü vaat edilerek, çocuklara oyunu oynamaya meyilli olması sağlanmaktadır.

\section{4 | SONUÇ VE ÖNERÍLER}

Sosyal Popüler kültür kavramı günümüzde genç kitlenin doyumsuz bir tüketim eylemine yönelmesine neden olmaktadır. Popüler kültür, kitle iletişimi yönünde ticari amaçlı olarak popüler kültür ürünlerinin bir kitle pazarı haline gelmesine neden olmuştur. İletişim teknolojilerinin gelişmesinin getirdiği dönüșümlerden biri olarak tüketim eylemlerinde artık popüler kültür etkisinin yoğunlaşarak ürünlerin tüketiminde büyük bir kitlenin popüler ürünleri tüketme isteğine sebep olmuştur. Bu yönde yeni iletişim araçlarının getirdiği yeni reklam mecraları da büyük önem taşımaktadır. Özellikle Advergame uygulamaları bu yönde tüketim eyleminin popüler kültür ürünleri yönünde satın alma davranışını geliştirmesinde önemli bir yere sahiptir. Bilim ve teknolojinin gelişmesine paralel olarak; popüler kültür bir meta haline dönüștürülmüş ve sanayi ürünleriyle birlikte tüketilmeye başlanmıştır. Yani bir bakıma kitlesel iletişim araçlarıyla birlikte hızlı bir şekilde talep edilme ve tüketilmede artış gösterilmiştir çünkü tüketim sınırları boyutunu aşmış adeta çlgınlık haline dönüşmüştür böylece kapitalist pazar ilişkilerine dönük yapısını destekleyen İnsanlar sadece maddi olanı tüketmemekte olup tüketime harcadığı vakitle zamanı da tüketmiş olur.

Kitle kültürü çerçevesinde reklam mecralarının değişmesi ve bu yönde eski tüketim alışkanlıklarını adeta bir eritme potası işlevine sahip olduğunu göstermektedir. Bir toplumda toplumsal ve bireysel ihtiyaçlar ve tercihler yönünde farklılıklar olmasına karşın, popüler kültür çerçevesinde tüketimi arttıran Advergame uygulamaları yaşam alanlarını da sanal boyuta tașlyarak reklam ve oyunu birleștiren bir çerçevede yeni bir yaşam tarzı sunmaktadır. Ancak günümüzde bu hızlı ve değişen tüketimin de kişileri tek tipleştirdiği ve hızlı tüketim eyleminin küresel bir tüketim ideolojisi yaratarak popüler kültür ve tüketim çalışmaları yönünde incelenmesi ve tartışılması gerekli olan önemli sorun alanlarından biri olduğu da göz ardı edilmemelidir. $\mathrm{Bu}$ yönde internet üzerinden hız kazanan tüketim eylemlerinin Advergame ile birlikte yeni bir boyut kazanması sınır tanımayan bir kültürün yeni versiyonunu oluşturmaktadır. Kitle iletişim araçlarının yaydığı popüler kültür günümüzde dijital yeni çağla birlikte dijital reklam platformlarından egemenliğini sürdürmeye başlamıştır. Dönüşümlerin ve yeniliklerin dışında olmadan bu yeniliklere uyum sağlayarak ancak bu yenilikleri tüketimi sevdirecek eğlenceli bir konuma getirmede yararlı olduğu düşünülmektedir.

Markalar ürünlerinin reklamlarını toplumu sıkmadan onları eğlendirerek yaptıkları reklam kampanyalarında hep başarılı olmuşlardır. Başarılı reklamlar tüm markaların istediği bir şeydir. $\mathrm{Bu}$ yüzden Advergame sayesinde bu başarıları yakalayan markalar bu yolda ilerleyerek Advergame yöntemini kullanarak tüketiciye ulaşmaya devam etmektedirler. Markalar ürünlerinin reklamlarını kullanıcıları sıkmadan aksine onları eğlendirerek yaptıkları reklam kampanyalarında hep başarıya ulaşmışlardır. Başarılı reklamlar tüm markaların istediği bir şeydir bu yüzden Advergame sayesinde bu başarıları yakalayan markalar bu yolda ilerleyerek zaman aralıklarıyla Advergame yöntemini kullanarak 
kullanıcıya ulaşmaya devam etmektedirler bununla birlikte arttırılmış gerçeklik ile reklam kampanyalarında farklılaștırma, ilgi çekicilik, tutundurma çalışmaları yaratılarak reklam kampanyalarında öncü durumundadır ayrıca bu teknoloji günümüzde geliştirilerek ilerideki kuşaklarda; eğitimde, işletmelerde, tıpta vb. birçok alanda kullanılacaktır.

Sonuç olarak modern toplumda teknoloji ilerledikçe popüler kültürü ve tüketim kültürü değişmektedir. Buna bağlı olarak reklam tarzları da yenilenmektedir. Son zamanlarda insanlar artık tüketerek tatmin olmaktadırlar. Medya kültürünün de bu değişimde etkisi büyüktür. Topluma tüketme yoluyla mutluluğu vaad etmektedir. Sürekli yenilikler getirerek, ürünleri cazip göstererek kapitalizm bu sistemi canlı tutmaktadır. Günümüzde artık çocuklar da teknolojiye ayak uydurduklarından onlar da bu tüketim kitlesine dahil olmaktadır. Artık reklamlar tüketicinin dikkatini çekebilmek ve istek oluşturabilmek için daha özgün olmaktadır. Advergame de çocuklara yönelik bir reklam çeşididir. $\mathrm{Bu}$ Advergame oyunlara bakıldığında bu oyunlar ile hem ürünler sunulmakta hem de çocuklara çeşitli eğlence mecraları ve ödül bazlı rekabet oluşturularak zaman geçirmeleri sağlanmakta olduğu görülmektedir. Bu yüzden bu reklam oyunları çok tercih edilmektedir.

Advergame uygulamaları bireylerin popüler kültür çerçevesinde tüketim edinimlerinin artmasını sağlamaktadır. $\mathrm{Bu}$ uygulamalarda hedef kitlenin yalnızca çocuklar ve gençlerle sınırlı kalmayıp geniş bir kitleye de hitap edebilmesi reklam çalışmalarının etkinliğini de dijital ortamda artırmaktadır. Reklam çalışmalarının eğlenceli bir etkinlik olarak da sunulması bireylerin advergame uygulamalarına ilgisini sağlamaktadır. Advergeme, reklam çalışmalarında markanın popüler uygulamaları yansıtarak markaya olan ilginin artmasını ve kullanıcılara sunulan eğlence içerikli reklamları oyuna çevirerek farklılı yaratabilmeye olanak tanımaktadır.

\section{KAYNAKÇA}

Aktaş, H. (2011). Internet Reklamcılı̆̆ı, Tablet Kitabevi: Konya

Akyol, Mevlüt (2010). Marka İletişim Aracı Olarak Oyun Reklam: Marka Farkındalığı Oluşturma Rolü Üzerine Bir Çalışma. Selçuk Üniversitesi Sosyal Bilimler Enstitüsü Doktora Tezi, Konya

Barnet, R., Cavanagh, J. (1995). Küresel Düșler, Imparator Sirketler ve Yeni Dünya Düzeni, Sabah Yayınları: İstanbul

Bozkurt, Y. (2015). Oyun Reklam Algısı ve Bu Algının Markaya Yönelik Tutum İle Davranış Niyeti
Üzerindeki Etkisi. Eskişehir Anadolu Üniversitesi Sosyal Bilimler Enstitüsü Halkla Ilişkiler ve Reklamcılık Anabilim Dalı. Doktora Tezi, Eskișehir

Chen J., Ringel, M. (2001). Can Advergaming be the Future of Interactive Advertising? http://locz.com.br_loczgames_advergames Erişim Tarihi: 17.12.2019

Dahl, S, Eagle, L. and Baez, C. (2006). Analysing Advergames: Active Diversion or Actually Deception, Middlesex University Business School Discussion Paper Series, Middlesex University Business School: London.

Elden, M. (2009). Reklam ve Reklamcılık, Say Yayınları: İstanbul.

Erdoğan, İ. (1999). Popüler Kültür: Kültür Alanında Egemenlik ve Mücadele. Popüler Kültür ve Iktidar. Vadi Yayınları: Ankara

Güney, Z., (2006). Etkileşimli Reklam Yaratma ve Planlama Süreci, Marmara Üniversitesi Yüksek Lisans Tezi, İstanbul.

Ilgın, H. Ö. (2013). Advergaming ve Marka İlişkisi The Turkish Online Journal of Design, Art and Communication

Kahraman, H.B. (2003). Kitle Kültürü: Kitlelerin Afyonu, Agora Yayınları: İstanbul

Kurtuluş, Ö. Popüler Kültür Kavramı http://ozgurkurtulus.com.tr/populer-kulturkavrami Erişim Tarihi: 07.11.2019

Marolf, G. (2007). Advergaming and In-Game Advertising: An Approach to the Next Generation of Advertising, VDM Verlag: Saarbrücken

Oskay, T. (2016). Oyun Reklam Uygulamalarının Görsel Tasarım Özelliklerinin Kullanıcılar Üzerindeki Etkisi: Uludăg Lezzet Dünyası ve Gez Göz Sneıjder Oyun Reklamlarının Incelenmesi. T.C. Kocaeli Üniversitesi Sosyal Bilimler Enstitüsü Yüksek Lisans Tezi

Oskay, T., Koçer, S. (2016). Bir Etkileşimli Reklam Aracı Olan Oyun Reklam (Advergamıng) Üzerine İnceleme. 2.Uluslararası Medya Calışmaları Kongresi Antalya

Özbek, M. (2002). Popüler Kültür ve Orhan Gencebay Arabeski, İletişim Yayınları: İstanbul

Özkaya, B. (2010). Reklam Aracı Olarak Advergaming. Marmara Üniversitesi I.I.'B.F Dergisi, (2), 455-478.

Öztürk, M.C. ve Coşkun, E. (2017). Oyuncu Motivasyonlarının Advergame Uygulamaları Açısından Değerlendirilmesi. Karadeniz Teknik Üniversitesi İletişsim Araştırmaları Dergisi, 4(13), 4864 
Perez, J. (2010). What is Advergaming: Advertising via Video Game, http://earticles.info/e/a/title/Whatis-Advergaming:-Advertising-via-video-games Erişim Tarihi: 10.10.2019

Santos, E., Gonzalo, R. ve Gisbert, F. (2007). Advergames: Overview, International Journal Information Technologies and Knowledge 1 (3), 203208.

Soytürk, T. (2008). İnternet Reklamcılı̆̆ Oyuna Koşuyor. MediaCat Dergisi, 16, (165).

Torlak, Ömer (2000), Tüketim: Bireysel Eylemin Toplumsal Dönüşümü, Inkilab Yayınları: İstanbul

Winkler, T., Buckner, K. (2006, Fall). Receptiveness of gamers to embedded brand messages in advergames: Attitudes towards product placement. Journal of Interactive Advertising. 7(1).

Yamamoto, G. T. ( 2009). Oyun, Internet, Advergame ve Mobil Oyun, PÍ Pazarlama ve Íletişim Kültürü Dergisi, 8 (29), 17-22.

Yanıklar, C. (2006). Tüketimin Sosyolojisi, Birey Yayınları: İstanbul

Yeygel, S., ve Köseoğlu, Ö. (2006). İnteraktif Pazarlama Çağında Yeni Bir Reklam Ortamı Olarak Virütik Oyunlar Ve Advergaming Kavramı, Yeni Iletişim Ortamları ve EtkileGim Uluslararası Konferansı

Yüksel, M. (2007). Küreselleşme Sürecinde Yeni Bir İletişim Ortamı, Öneri Dergisi, 7 (28) 317-326

http://www.hurriyet.com.tr/gundem/hem-reklamhem-oyun-advergame-5585115 Erişim Tarihi: 07.11.2019 